\title{
The Aims and Methods of Liberal Education: Notes from a Nineteenth Century Pan-Africanist
}

\author{
Robbie Shilliam ${ }^{1}$
}

Published online: 7 June 2016

(C) The Author(s) 2016. This article is published with open access at Springerlink.com

\begin{abstract}
Liberal education is in crisis as neoliberal logics continue to shape the purpose and practice of higher education. But despite invocations of its contemporary 'global' context, very few commentators engage the current crisis through the provocations of postcolonial studies. A key element of postcolonial critique draws attention to the ways in which the modern humanities and social sciences are colonially inflected traditions of knowledge production. Taking this critique as a point of departure, I aim to show that the critical response to the crisis prompted by the neoliberal agenda is inadequate in so far as there has been insufficient acknowledgement that modern liberal education wishes to suture and save a public culture that is racially exclusionary. To open up this space of inquiry, I focus on the thought and practice of Edward Blyden. Born in St Thomas, Danish West Indies, Blyden migrates to Liberia. A prolific writer and educator, Blyden delivers, in 1881, his inaugural address as President of Liberia College entitled 'The Aims and Methods of a Liberal Education for Africans'. What lessons for the present crisis might we draw from a nineteenth century Pan-Africanist advocate of liberal education?
\end{abstract}

Keywords Neoliberalism $\cdot$ Liberal education $\cdot$ Pan-Africanism $\cdot$ Race $\cdot$ Colonialism $\cdot$ Liberia . Blyden

\section{Introduction $^{1}$}

Liberal education is in crisis. Commonly traced back to the classical Greek pedagogy of eleutherios paideia, the tradition of liberal education is supposed to free the pupil from habit so

\footnotetext{
${ }^{1}$ Thanks to Gurminder Bhambra and John Holmwood for critical comments; thanks to anonymous reviewers for advice; and thanks to Alf Nilsen for the gracious invitation to contribute to this issue. My interest in Blyden's pedagogy was first piqued in a summer school seminar led by Erna Brodber.
}

Robbie Shilliam

r.shilliam@qmul.ac.uk

1 School of Politics and International Relations, Queen Mary University of London, Mile End Road, London E1 4NS, UK 
as to become fully human by cultivating an inquiring mind and a virtuous character committed to pursuing the public good (Axelrod 2002, pp. 11-13; Cronon 1998). But for some while now, observers have bemoaned the progressive loss of the spaces within the Western academy that would serve such a pedagogy. Many point to a relentlessly creeping neoliberal logic that disaggregates society into interest-maximizing individuals and that responds only to the demands and interests of capital. The force of such logic upon the academy, critics argue, has led to a progressive displacement of the ethos of liberal education that links critical inquiry and edification to the public good (see for example Harris 2005; Nussbaum 2010; Shore 2010). This shift is especially pronounced and contested in UK academia, as what has historically been a thoroughly public higher education system is now experiencing a game-changing withdrawal of government funding (see Holmwood 2011).

Despite invocations of its contemporary 'global' context (Nussbaum 2004), most scholars make sense of the crisis by reference to the standard canons of European thought that, in one way or another, pay homage to eleutherios paideia. Very few critics engage liberal education through the provocations of postcolonial studies, even though that, too, has become somewhat of a standard in the Western academy (for various exceptions, see Giroux 1992; Mohanty 1989). A key element of postcolonial critique draws attention to the ways in which the modern humanities and social sciences are colonially inflected traditions of knowledge production (see for example Seth 2007). Taking this critique as a point of departure, I aim to show that the critical response to the crisis of liberal education prompted by the neoliberal agenda is inadequate in so far as there has been insufficient acknowledgement that modern liberal education wishes to suture and save a public culture that is racially exclusionary.

More than simply a disclosure of discrimination, my article draws attention to the ways in which modern liberal education is complicit in committing epistemic injustice. Such an injustice refers to the ways in which some racialized groups are deemed competent to cultivate the public sphere while others are deemed incompetent to do so. The main purpose of my article is to retrieve a Black tradition of liberal education that is of relevance to the contemporary context precisely because it treats epistemic injustice, rather than neoliberal logic, as a problem of the first order. To my mind, Edward Blyden is the intellectual exemplar of this tradition. Blyden, born to free parents of Igbo descent in the Danish West Indies, migrates to Liberia in 1851 and there crafts a turbulent and contentious career as a politician and educator (for biographical notes, see Lynch 1978). In 1881, after being elected as President of Liberia College, he gives an inaugural address entitled 'The Aims and Methods of a Liberal Education'. His aims and methods directly address the question of epistemic injustice in the colonial context. It is my contention that, while its provenance is the Global South, Blyden's pedagogy might also help to more adequately address the crisis of liberal education in the Global North.

I proceed in three steps. First, I provide an argument as to why the defence of modern liberal education must reference epistemic justice, and I do so specifically by historical reference to the UK context of higher education and the struggles of peoples of African heritage against racism in the British public sphere. Second, I turn to Liberia in the late nineteenth century. I explicate Blyden's aims and methods of liberal education as a direct response to the republic's colonial project that conceived a public culture by pitting a (relatively) 'civilized' African-American settler population against the indigenous peoples of those lands and their 'primitive' practices. Finally, in a conclusion, I return to the UK context in order to suggest the difference that Blyden's pan-African pedagogy might make to the current defence of liberal education. The North can learn from the South-and the South in the North. 


\section{Liberal Education and Epistemic Injustice}

The current articulation of liberal education emerged as a response from Oxford dons to a challenge mounted by the Edinburgh Review in 1808. The Review argued that Oxford University was unable to engage with the challenges to the traditional order now presented by the growth of what the Scots had termed 'commercial society'. The Oxford curriculum, charged the Review, still focused upon the classics, divinity and mathematics at the expense of meaningfully incorporating subjects that engaged with and arose out of the growth of industry and the world market - e.g. natural science, political economy, commerce and law (Slee 1986, pp. 9-10). Edward Copleston, then Dean of Oriel College, Oxford, replied defensively that, indeed, students could take instruction in political economy; however, 'it is never forgotten ... to lay a foundation of liberal literature, ancient and modern, before any particular pursuit absorbs the mind'. (Copleston 1810, p. 154). Soon afterwards, John Henry Newman drew upon the Oriel environment and Copleston's response to provide a positive manifesto of liberal education (see Higton 2012:, p. 81). The 'habit of mind' that such an education formed, argued Newman, was not to be valued in terms of its direct usefulness to modern industry or administration but rather in its cultivation of a virtuous character (Newman 2008, p. 114).

More than hierarchies of subject matter are at stake here. This tradition of liberal education, as it has been transmitted into the present day, seeks to suture the divisive, instrumentalizing and individualizing effects of modernity with a classical tradition of pedagogy that cultivates a virtuous intellect committed to the public good (Carnochan 1993, p. 29). Such contentions have returned regularly in debates over the purpose of British higher education at various moments in the development of the public university system (see for example Oakeshott 2004). The Robbins report of 1963 marks one such crucial intervention.

The Robbins report is famous for marking an era of significant expansion in the publicly financed higher education sector. What is important for our purposes is the fourth aim of higher education that the report stipulated: once the reserve of the privileged few, higher education would now have to perform a role in ameliorating social inequalities in an age that had set for itself 'the ideal of equality of opportunity' (Committee on Education 1963, p. 7). Specifically, higher education would be tasked with introducing 'that background of culture and social habit upon which a health society depends' to students whose 'home background' might have ill-prepared them for public life. In this respect, universities and colleges had 'an important role to play in the general cultural life of the communities in which they are situated' (Committee on Education 1963, p. 7). Through point four, then, the report articulated the aims of liberal education as an amelioration of social inequality, with the method of this education being 'the transmission of a common culture and common standards of citizenship' (Committee on Education 1963, p. 7).

Curiously, in arguing for the transmission of a common culture as a method of liberal education, the Robbins Report made no reference to one of the most fundamental demographic transformations of the time: the steady arrival into the 'mother country' of peoples from Britain's old or ex colonies. Crucially, these arrivants quickly experienced racialized discriminations and exclusions that defined much of their engagement with public institutions, even though many of them were public sector workers. Indeed, the infamous Smethwick election campaign, fought upon a racist anti-immigration platform, took place just 1 year after the Robbins report was published. There is, then, a curious evasion in the report's engagement with liberal education of the wider postcolonial challenges to the "transmission of a common culture' that were evidently gathering pace. 
At this point, I want to offer a reason for this evasion. As I have mentioned, the inherited framework through which to defend the aims of liberal education references a standard dialectic of modernity, i.e. the preservation and progression of virtue and the public good in a social context racked by the anoymizing and instrumentalizing forces of capitalism and bureaucracy. However, this dialectic does not constitutively reference the colonial projects of many European polities, which, a number of scholars have argued, are congenital to the very birth and logic not just of modernity per se but of the way in which modernity is conjoined with the nation-state (see Bhambra 2013; Mignolo 2011). Contextualizing the defence of liberal education within a global colonial-modernity — and not just a European/national modernity-leads us to question which divisions liberal education is supposed to suture and whose public good it is supposed to serve.

Here, we must turn to the influence of Matthew Arnold, the pre-eminent English cultural theorist of the nineteenth century (Carnochan 1993, pp. 24-25). Arnold's work, as he saw it (2003, pp. 35-37), was in part a contribution to the historical debate over the Oxford curriculum and Newman's manifesto for a liberal education. Arnold emphasized the use of 'culture' as the method by which the 'best knowledge' could be mobilized for 'the moral and social passion for doing good' (Arnold 2003, p. 8). This function of culture was especially important in a 'modern world' that had become more and more 'mechanical and external' (Arnold 2003, p. 15). Arnold conceived of this cultivation of knowledge as a paternalistic method to pursue what had previously been called the 'improvement' of the lower classes. As Arnold (2003, pp. 17-18) put it, through culture the 'raw person' ceased to follow the 'rule by which he fashions himself' and drew 'ever nearer to a sense of what is indeed beautiful, graceful, and becoming'. The influence of Arnold on the subsequent debates over liberal education is clear. The same sentiments that affirm an epistemological distinction between 'high' and 'low' culture are easily identifiable in the strong paternalism of the Robbins Report wherein liberal education is tasked to cultivate those whose home background had made them 'ill prepared' for public life.

Paternalistic, yes. But Arnold's schema is also influential in its racializing of the social parts that made up the nation including the dissonance between parts that provided for the growth of culture (Leerssen 2006; Young 1995, p. 56). As Robert Young (1995, p. 54) notes, Arnold derived his high/low culture distinction from the colonial anthropological/sociological frameworks of the time. Hence the bearers of low culture, 'raw' in reference to those frameworks that racialized nonEuropean peoples as 'primitive', had no competencies through which to contribute to culture, that is, the method by which the 'best knowledge' cultivated the public good. This is why Arnold believed that 'primitive' cultures internal to the British nation - for example, Celtic — should be publicly represented only as dead traditions, that is, objects of antiquarian interest (Leerssen 2006, p. 68). In this way culture, as Arnold paternalistically framed it, could be racially exclusionary at the same time as it professed to be socially ameliorative.

Let us remember that the transmission of this public culture was precisely the method of liberal education, as Robbins defined it, in his era where real-and not metaphorical-'primitives' now intimately constituted one part of the British nation. I submit, therefore, that the oft-vaunted dialectic of liberal education-virtuous public good as a salve for the instrumentalizing and alienating machinery of modernityobfuscates the racializing and exclusionary logics of colonial-modernity, exclusionary logics that liberal education reproduces even as it works to salve the divisions of modernity. And in order to draw out the political significance of this obfuscation, I would now like to properly introduce the notion of 'epistemic justice'. 
Epistemic justice calls for a reckoning with the racialized inequalities of knowledge cultivation that have historically accompanied the European colonial project. Complicit in this form of injustice is the cognitive framework of colonial-modernity itself, which categorically segregates humanity into different meta-groups: the moderns, who deem themselves competent to rule themselves and others, and the sub-modern or traditionals whom moderns deem incompetent to rule themselves (de Sousa Santos 2007). Epistemologically, and as we have seen with Arnold's conception of public culture, this segregation creates the knowers and the known, that is, those groups who are racialized as competent to produce adequate and universalisable knowledge of the modern world and those who are racialized as incompetent to do so. Epistemic justice rejects this cognitive framework of colonial-modernity when it comes to deciding what counts as adequate knowledge and who counts as adequate knowers (Keet 2014; Restrepo 2014).

This is where epistemology and politics connect. In colonial-modern frameworks, colonized communities and/or their postcolonial descendants living in the Global North are represented as collective entities whose cultures lack epistemic authority in contrast to the norms and procedures of the civilized colonizers and their descendent institutions. In other words, public culture delineated along colonial-modern lines objectifies postcolonial communities as exogenous problems that confront national institutions and then require, at best, a paternalistic assimilative response and at worst a violent disavowal. In contrast, epistemic justice affirms that the knowledge systems of such communities (including their fault-lines) are resources that, in principle, hold epistemic authority when it comes to identifying what counts as a problem, what constitutes the problem and what are the means of redress. Epistemic justice is therefore a crucial dimension of the wider struggle for reparation of colonial injustice (see Grosfoguel 2007; Icaza and Vázquez 2013).

Such a critique has significant implications for liberal education, especially of the kind promoted in the Robbins report and inflected through Arnold's racialized framing of public culture. For if liberal education is not sensitive to epistemic injustice then it runs the risk of being (paternalistically) ameliorative in its aims but racially exclusionary in its methods and thus unfit for its own purpose. In what now follows, I chart the shifting terrain in UK higher education whereby struggles for epistemic justice briefly confronted the exclusions of liberal education before being sidelined at the same time as liberal education itself became increazingly displaced by neoliberal agendas.

The 1997 Dearing Report, the next major review of higher education following Robbins, was clearly influenced by neoliberal logic in so far as it articulated a valuation of higher education in terms of its prospective contribution to national economic competitiveness (Bell and Stevenson 2009, p. 7). Specifically, one of the report's key recommendations, to replace maintenance grants with student fees, signalled a change in the valuation of higher education away from a public good and towards privatized capital. Nevertheless, the report still referenced the aims of liberal education in so far as higher education was tasked with playing 'a major role in shaping a democratic, civilized, inclusive society' (The National Committee of Inquiry into Higher Education 1997, pp. 72, 81). The report also explicitly referenced Robbins' method of liberal education - the 'transmission of a common culture' (The National Committee of Inquiry into Higher Education 1997, p. 64). However, the Dearing report admitted that the notion of a common culture was now far more problematic than Robbins had assumed, and this was due at least in part to the iniquitous position of 'ethnic minorities' in UK society (The National Committee of Inquiry into Higher Education 1997, pp. $22,80,105,223)$. 
In fact, in the era spanning Robbins and Dearing, many 'ethnic minority' communities had made it known only too clearly that they would not accept the racialized inequalities and discriminations that had accompanied their insertion into and residency within the 'mother' country. What I want to briefly draw attention to here, focusing on communities of African heritage (which for the purposes of this article I term as Black), is the epistemic dimension of these struggles for justice. For instance, in response to the formal designating of many AfricanCaribbean school children as educationally subnormal (Coard and Caribbean Education and Community Workers' Association 1971), mothers as/and community activists began Saturday supplementary schools. There, maths and English were often taught alongside Black history, a discipline that had been established and spread by community intellectuals. Black intellectuals were active further afield too, for example, radicalizing the Institute of Race Relations. Epistemic justice was also pursued through various artistic endeavours - from the Black agitprop of the Keskidee theatre troupe to Rastafari sound systems, all of which cultivated collective self-understandings of and remedies for living in the heart of 'Babylon' (see variously Alleyne 2002; Gutzmore 1982; Henry 2006; Mirza and Reay 2000; Shilliam 2015, Chapter 4).

At the same time, and enabled by the expansion of higher education legitimized by Robbins, increasing numbers of 'non-traditional' students (including Black peoples) entered into the public education system and unavoidably brought with them 'non-traditional' concerns of race and gender (Bhambra 2015). In this context, the wider movements for epistemic justice in Black communities even influenced academia, although the link between university and community-based intellectuals was usually tenuous. Nonetheless, the research agenda of Stuart Hall and others made an incisive intervention into the Arnoldian legacy by investigating the ways in which national culture, the supposed transmitter of a common culture and standard of citizenship, was oblivious to its colonial articulation and racialized exclusions (Hall 1990; Solomos 2001). The new cultural studies influenced many Black students who were entering higher education in increasing numbers, with some following through to doctorate work (see in general Baker et al. 1996; Owosu 2000). The institutional hostility that met this Black intervention into academic life in the UK has yet to be sufficiently detailed and fully reckoned with. Some key Black cultural studies intellectuals found the USA far more conducive to career prospects than their domestic British academy. And anecdotal evidence that I have heard suggests that those who remained in the UK as Black scholars undertaking research on race and racism (often with community commitments) tended to be devalued and marginalized by the rise of managerial performance indicators wedded to neoliberal logics such as the Research Assessment Exercise.

Meanwhile, a key concern of the Dearing report, and one re-stated in subsequent policy papers, was to make Britain more competitive in an increasingly knowledge-driven global economy (Bell and Stevenson 2009, pp. 8, 11). Many critics have argued that the activities that constitute internationalization - student exchanges, research collaboration, etc.- have been increasingly hijacked for neoliberal purposes, most of all, to gain a larger share of the global market in higher education (for example Kim 2009; Stromquist 2007). True, sectoral reports in the UK raise aspirations to ensure that the curricula of international programmes engage with ethical issues associated with inter-cultural knowledge production (The Higher Education Academy 2014). But in practice, these programmes usually focus on individualized investment and the provision of what De Vita and Case (2003) term a 'mono cultural model of internationalization for financial gain'.

There has been, though, another consequence to the internationalization agenda beyond the usurpation of a pedagogical space to cultivate the (global) public good. Bound up with the 
struggle against racism that I glossed above, the 1976 Race Relations act was amended in 2000 to place statutory duties on public institutions - which in the UK still includes universities - to ensure that their policies and procedures are not racially discriminative. However, what was once a concern to address racialized inequalities in higher education has become obfuscated by the desire for ethnic diversity, a desire that is in good part related to competing in a global market for international students (Ahmed 2007, p. 242; Equality Challenge Unit 2010, p. 9). (This obfuscation is embedded in wider shifts in race talk towards a language of 'multiculturalism' (see Lentin 2005)). Additionally, as university functions have increasingly become monetized, income-generating functions (such as internationalization/diversity) are being maximized while other non-monetized functions, especially equality issues, have been given, in comparison, cursory and procedural attention. In this respect, diversity achieved through the recruitment of international (often — but not always - elite) students has displaced the historical pursuit of epistemic justice for resident and structurally marginalized ethnic minority communities (see Ahmed 2007, pp. 237, 240).

There is one more chapter to this story. In 2010, Lord Browne delivered an extremely controversial report on the future financing of higher education. Unlike Dearing, Browne's report did not even mention Robbins fourth principle of higher education in Britain, i.e. the aims and methods of liberal education. Subsequent to the report, the coalition government withdrew government funding for social science, arts and humanities degrees. This radical departure from the very notion of a publicly funded higher education system drew a series of demonstrations as well as a concerted campaign in defence of the public university system (http://publicuniversity.org.uk/). A critique of the Browne Report by Stefan Collini (2010) has become oft cited in which he identifies the stakes at play:

whether universities in the future are to be thought of as having a public cultural role partly sustained by public support, or whether we move further towards redefining them in terms of a purely economistic calculation of value and a wholly individualistic conception of 'consumer satisfaction'.

I am not opposed to Collini's critique of neoliberalism. I would defend the continued existence of a system of public higher education, but I do worry specifically about the silences that are activated in the defence of a public cultural role for universities which references only the traditional problematique of modernity. ${ }^{2}$ It is not good enough to claim that the defence of the public good is a prerequisite for the pursuit of social justice per se. For what in the first place is just about the 'transmission of a common culture and standard of citizenship' that is colonial-modern in its constitution? What are the limits of restitution when the very constitution of public culture has been not just paternalistic but epistemically exclusionary? There is, in short, a curious silence here on the provocations of the postcolonial critique, very similar to that of the Robbins report, almost 50 years prior.

And so I want to inquire into a defence of liberal education that confronts colonial-modern exclusion as a first order problem, one that is mindful of the challenge of epistemic justice as a problem of the first order. Let us remember that there are alternative genealogies of liberal education. I am thinking not so much of the ways in which Matthew Arnold was taught to the 'native intellectuals' of British colonies, although that is important (Gikandi 2007). Rather, I am thinking of the work of intellectuals from the colonies who, despite being racialized as epistemically incompetent to undertake such a high-minded task, nevertheless proceeded to

${ }^{2}$ I thank Gurminder Bhambra for clarifying this distinction between system and culture. 
espouse aims and methods of liberal education that exceeded the imagination and reach of Oxford dons and those who share with them a common culture. In this respect, the writings of Edward Blyden demand especial attention.

\section{The Aims and Methods of a Liberal Education for Africans}

January 5th, 1881. Blyden uses his inaugural address as President of Liberia College to promote a liberal education informed by a pan-African pedagogy that he has crafted over the decades. (In what follows, I augment his 1881 speech with a number of his writings that precede and succeed this moment). The paramount aim of liberal education, Blyden announces, is to enable the returning descendants of enslaved Africans trafficked across the Atlantic to 'become one with the great tribes on the continent' (Blyden 1882, p. 3), and in this respect, Blyden is obsessed with the relocation of Liberia College from Monrovia to the 'interior'. The key method of liberal education, Blyden argues, is the teaching of a curriculum that excludes European conceptions of the worth of African peoples. Blyden's aims and methods are intended to address the specific paradoxes of the colonizing project that has eventuated in the republic of Liberia.

At its inception, the emigration of African-Americans to the colony of Liberia is perceived by the diverse constituencies of the American Colonization Society (ACS) as a pressure release valve for the energies released through the struggle over the South's 'peculiar institution' of slavery (see Moses 1998, pp. xvi-xvii; Tyler-McGraw 2007): here the question of what to do with 'freed Blacks' is foremost. To the religious-minded members of the ACS, African-American settlers in Liberia are perceived as a force that might create a beachhead for the (colonial) Christian evangelization of the African continent (Gershoni 1985, p. 9). AfricanAmerican settlers are not a homogeneous mass nor necessarily all evangelical (Tyler-McGraw 2007, pp. 179-180). Nonetheless, the Liberia project carries within its very blueprint the same fundamental animosity and exclusionary practices towards indigenous peoples that is one of the original sins of the colonization of the Americas (Akpan 1973, pp. 220-221; Gershoni 1985, p. 24). Although in situ Black, the settler status of African-Americans still relies upon the racializing logics of European colonialism to render them relatively civilized in comparison to the 'primitive' indigens. And so, post-independence, Liberia's Black governors consider their new republic to be a 'true' America where its laws and religion will be practised absent of the evils of slavery and racism - but not colonialism. Hence the settler elites cleave aesthetically and ideologically to their 'civilized' American identity (see Akpan 1973, pp. 219-225).

Meanwhile in 1828, Yale College responds similarly to Oxford University to the challenges presented by a rapidly industrializing continental economy. However, in defending liberal education, the dons of Yale must also address the challenge of integrating a set of somewhat distinct American colonies into a postcolonial—but still slave-holding — republic (Herbst 2004). The plan to build Liberia College is conceived in 1851 by members of the Massachusetts Colonization Society and, funded by two other societies, is inaugurated in 1862. Designed along the lines of a quintessentially American college, Liberia college professes the colonial-republican ethos of a liberal education championed by Yale: to promote public works and the public good and to disarm divisive social elements. Despite being the first of its kind to boast a specific remit to educate Black students, the college also professed a strong intention to civilize - that is, Christianize - the indigenous peoples in Liberia, who present one of the foremost threats to the integrity of the settler-colony/republic (see in general Livingston 1972). 
Blyden develops his pan-African pedagogy in direct confrontation with the Liberian republican ethos wherein the 'public', at its inception, excludes indigenous peoples racialized as primitives. Against this ethos, Blyden argues that the character of the African-American settler has already been mal-developed by the racist environment of the USA - although the 'body has been set free', 'the soul remain[s] in bondage' (Blyden 1908, p. 5, 1976a, p. 115). Blyden's argument is an implicit critique of Arnold's epistemic division of high and low culture in so far as Blyden identifies the brutality and deracination that this division requires. Hence, Blyden refutes the paternalism of the 'highly cultured' and makes the racially exclusionary effects of the 'transmission' of their 'common culture' the foundational concern for liberal education.

At this point, I need to acknowledge the contradictory colonial registers and rhetorics deployed in Blyden's written work, as detailed in Teshale Tibebu's (2012) insightful commentary. Nonetheless, it is clear to me that, behind the registers and rhetorics, Blyden's Pan-African pedagogy seeks primarily to dismantle the colonial-modern framework that makes of indigenous peoples objects to be known and manipulated - or destroyed - and settlers the knowing subjects destined to govern themselves and others. Crucial, here, is Blyden's acknowledgement and assertion that indigenous peoples have valid knowledge of the geo-cultural context in which settlers find themselves $(1882$, p. 11). Blyden even considers it a great error that settlers should perpetuate 'race antagonism' towards indigenous peoples who are, in fact, 'more industrious, more intelligent, and better organized' (Blyden 1882, p. 27, 1978d). In other words, Blyden charges the public culture of Liberia with an original epistemic injustice.

It is in this light that we must approach the key aim of Blyden's liberal education: the relocation of Liberia College to the interior. Blyden often conjures the cartographic image of a colonized seaboard with its 'physical and moral malaria' in opposition to the healthy interior where the race still holds its 'integrity', 'untouched by foreign influence, nor yet affected by European habits' (Blyden 1882, p. 4, 1908, p. 29, 1976b, p. 127). It is important to note that Blyden does not cease to complain of the resistance to any relocation of Liberia College by the settler elite (see for example Blyden 1978a, pp. 315-316). His abiding concern is to divert any influx of African-American settlers who might wish to violently 'push inwards', sanctioned by the predicates of 'race hierarchy' (Blyden 1882, p. 13, 1976a, p. 117). It is almost as if Blyden sees Liberia College as racing ahead of these forces in order to set the terms of engagement through epistemic justice rather than colonial injustice. Such concerns are clear in his inaugural address:

that is why we want the College away from the seaboard with its constant intercourse with foreign manners and low foreign ideas - that we may have free and uninterrupted intercourse with the intelligent among the tribes of the interior; that the students, even from the books to which they will be allowed access, may conveniently flee to the forests and fields of Manding and the Niger, and mingle with our brethren and gather fresh inspiration and fresh and living ideas. (Blyden 1882, p. 28)

How does Blyden conceive of the positive effect that this physical movement might have upon a liberal education for Africans?

We must first note that Blyden roots his critique of epistemic injustice in the very environment through - and about which - knowledge is produced. As the relatively civilized 'knowers', African-American settlers conceive of indigenous practices of agriculture, land tenure, and living arrangements as epistemically invalid (Blyden 1908, p. 3). Instead, Blyden charges settlers with deploying ill-fitting Euro-centric frameworks that are predicated upon 
premises of scarcity, industriousness and laws of private property, i.e. the fundamental structuring principles of modernity (Blyden 1908, pp. 17, 26). Blyden goes so far as to call this importation 'a transgression of natural law' (Blyden 1908, p. 15).

The natural law that Blyden references here - he also glosses it as the 'laws of growth for the [African] race' (1882, p. 11) - is cultivated from the clues and cues for pursuing the public good that God has left in the specific environment that surrounds and works through the traditions of indigenous peoples. In this respect, the committing of epistemic injustice by settlers upon indigenous peoples outlaws for the former any substantive education in the natural laws of Liberia. Instead, structurally predisposed to importing colonial-American practices wholesale, settlers, as Blyden (1908, p. 15) notes, have 'always in the long run create[d] wildernesses instead of farms and cities'. Alternatively, Blyden is convinced that Indigenous peoples must, in principle, be acknowledged as the most sophisticated practitioners of the natural law of their land. Therefore, their thought systems and cultural practices must be granted an epistemic authority:

we must learn to occupy the standpoint of our aboriginal brother [sic], and to believe that in his place there is no man under the sun better than or equal to him' (Blyden 1908, p.

29, see also 1976a, p. 116).

Concerned to pursue natural law in context, Blyden departs from Arnold's racially exclusivist conception of public culture by redeeming those supposedly 'non-modern' cultural parts of the Liberian republic as epistemically valid material for the edification of public virtue. And this claim upon epistemic justice is precisely what will ensure the fulfilment of liberal education's classical purpose: to free the (African) person from (colonial) habit so as to become (once more) fully human (see also Blyden 1908, p. 9, 1971b, p. 227). This is why Blyden argues in his inaugural address that when following the laws of the white man Africans 'can never attain to that essence of progress which Mr Herbert Spencer describes as difference' (Blyden 1882, p. 10). Spencer proposes an easily racialized/racializable conception of progress as an advanced industrial society differentiating itself from backward communities (internal and external). But Blyden understands difference differently, as an outcome of self-cultivation, as living otherwise to the racialized expectations of Europe:

In the course of our development laws will have to be made not known to Greek or Roman legislators; unheard of by [William] Blackstone ... which Napoleon never conceived ... The world would gain nothing by having the European reproduced in Africa'. (Blyden 1976a, pp. 118-119)

Indeed, Blyden is supremely confident that, so long as they follow the laws of the race in context, African peoples will be able to 'acquire the self-respect or self-reliance of an independent contributor [to humanity]' (Blyden 1882, p. 10).

I would now like to turn to the means, proposed by Blyden in his inaugural address, through which liberal education at Liberia College will be provided. Blyden envisages a curriculum that will rehumanize the African student so that she may proceed to cultivate the (natural) laws of the race. ${ }^{3}$ However, it is precisely at this point that Blyden proposes a

\footnotetext{
${ }^{3}$ It should be noted that Blyden is convinced that women should receive 'exactly the same general culture as we [men] do' and to share likewise in the 'pleasures of intellectual pursuits' (Blyden 1971c, p. 245). It is not clear whether Blyden envisages women taking leading public roles in Liberian society, but perhaps he has here been influenced by his observations of indigenous communities wherein women effectively run the markets.
} 
puzzling return to putatively European sources which, on the face of it, transgresses natural law in Liberia. Blyden is convinced that the Classics - that is, Greek and Roman literatureencourage the 'strengthening and disciplining of the mind' without 'unfavourably affecting our sense of race individuality or our own self-respect' (Blyden 1882, pp. 20-22) Indeed, a proper study of Greek and Latin, argues Blyden, provides an 'acquaintance with the best models of reasoning and eloquence, unequalled by anything to be found in modern European literature' (Blyden 1971c, p. 258). Is Blyden blindly following the prescriptions of Oxford and Yale dons? Or is there a subtle anti-colonial claim being made upon the Greeks and Romans?

To answer, we need to engage with the historical struggle for epistemic justice mounted by Black students in American higher education, which effectively confounds Yale College's defence of a colonial-republican liberal education. Colleges dedicated to the teaching of African-American students (of which Liberia College, although not in the USA, is nevertheless a leading centre) start to emerge prior to the American civil war but are bolstered greatly in its aftermath through the land grant system. A key contention of these Black colleges, famously expressed in the argument between Booker T. Washington and W.E.B. Dubois, is the purpose and extent of college education: should it be predominantly technical or also liberal? Washington's 'Atlanta compromise' accepts the continued disenfranchisement of southern Black peoples while allowing them access to further education only in the artisanal vocations. For Du Bois (1961, pp. 48-49), such a compromise reproduces the sub-humanity of AfricanAmericans in so far as it tacitly accepts that only white minds are competent to engage in the higher cultural realms of logos and mimesis. Contra Washington, Dubois argues that the souls of Black folk, once expressed only in the spirituals, now also require expression in these public realms (Du Bois 1961, p. 185).

This is why the opportunity to learn Classics is so valued by Black students and scholars in Blyden's era because these texts are perceived to be the vaunted repository of humanity. Hence, fluency in them for the descendants of enslaved Africans is perhaps less a case of embracing one's own racial incompetency and more a political statement on the equality of the faculties between races (see especially Goings and O'Connor 2011; Jarratt 2009). This statement, as Dubois suggests, is also a claim for an equitable presence within public culture. Blyden pre-empts Dubois when he argues, with regards to the Classics, that 'mind is everywhere the same; and every where it receives its character and formation from the same elementary principles' (Blyden 1971a, p. 220). And in his inaugural address, Blyden argues specifically that the Classics provide for a rehumanization of African intellect in so far as their study cultivates 'mental discipline without unfavourably affecting our sense of race individuality or our own self-respect' (Blyden 1882, p. 20).

Oxford and Yale dons seek to reposition the legacy of Greece within a dialectic of modernity that elides its colonial dimension: i.e. the (European) Greeks will provide the virtuous salve to European and American industrialization. But Blyden must re-situate the legacy of Greece within a broader struggle over colonial-modernity: virtue, if it is to mean anything, must also address epistemic injustice. Nonetheless, if the Classics are to be the instrument of rehumanization then a pedagogical challenge confronts Blyden: how to separate and quarantine modern racist European literature from its putatively 'European' classical tradition. For this purpose, Blyden divides European history into five or six epochs. The last two epochs are congenitally linked to Atlantic slavery and colonialism and roughly coincide with the European enlightenment and subsequent emergence of the science of modernity. The intellectual works created in these epochs will not be taught, regardless of their worth, as they either degrade African peoples or their defences of African peoples are 'patronizing or 
apologetic' (Blyden 1882, pp. 17-18). Literature from the preceding epochs - chief amongst these being the Classics-will be taught.

In this respect, Blyden sidesteps the appropriation of the Greeks as a dialectical force for suturing the alienations of modernity, and rather resituates the Greeks so that they might be used to confront the colonial-modern-and racially exclusionaryframing of knowledge and public culture. In fact, pre-empting the claims made by Martin Bernal in Black Athena, Blyden Africanizes the Classics by claiming that 'Greece sat at the feet of Egypt-Socrates, Plato, Pythagoras, Aristotle, all drank at the Egyptian fountain - and Egypt is in Africa' (Blyden 1976a, p. 117). There is also a sense in which (and perhaps it becomes stronger in his pedagogy in the years following 1881) Blyden apprehends the inclusion of the Classics as crucial only in so far as being a transitional state of affairs:

as we learn more and more of African customs and study more and more the kingdom of god within us, we shall find that the political economy of the white man is not our political economy, his moral philosophy is not our moral philosophy, and far less is his theology our theology (Blyden 1908, p. 20).

Perhaps, then, Blyden ultimately considers the Classics as a catalyst for the cultivation of Africa's own classical traditions, rather than as the global standard of intellectual measurement and cultural competency.

Finally, it is instructive to note that Blyden intends to teach Arabic and some of the 'principal native languages' in the College curriculum (Blyden 1882, p. 23). Despite its foreign provenance, Blyden finds Arabic more conducive to the demands of epistemic justice than English in terms of the mode of its acculturation by indigenous peoples. Although it is certainly a contentious argument, Blyden argues that, rather than being introduced through slavery, Islam came to Africans in their homes where they lived in 'a state of freedom and independence' and so were 'free to choose' (Blyden 1994, pp. 31-32). Therefore, in marked contrast to Africans living in Christian colonies (including in the Americas), African-Muslim communities and polities remain, in Blyden's opinion, 'self-reliant, productive, independent and dominant ... without the countenance or patronage of the parent country, Arabia' (Blyden 1994, p. 30). Thus, by including the teaching of Arabic and 'native languages' - and their cultural material-alongside and not below Greek and Latin, Blyden proposes a method by which a liberal education can serve epistemic justice in the face of colonial-modernity.

In summary, the problematique that Blyden forces the defenders of liberal education to address is the formation of a public culture that, being colonial-modern in its constitution, excludes the living knowledge traditions of peoples racialized as outsiders but who have in fact always been constitutive of the formation of the polity. Blyden's critique of epistemic justice speaks to the colonial intrusion of Black peoples from the North back into the lives of Black peoples in the South. But, as I shall now conclude, his critique also speaks to the colonial exclusions of Black peoples who remain in the North. For if Lord Robbins had read Edward Blyden, he would have perhaps realized that there can be no public service in the cause of equality of opportunity without the pursuit, at the same time, of epistemic justice. 


\section{Conclusion: Liberal Education and Epistemic Justice}

There is a Black tradition of liberal education the cardinal coordinates of which can be found in Blyden's pan-African pedagogy. Expressed broadly, Blyden's key aim of liberal education is to redirect the intellectual activities of (relatively) privileged Africans towards an equitable and intimate engagement with the collective thoughts and practices of their excluded and oppressed brethren and sistren; his key method is to provide a worldly curriculum that does not promote, assume or simply remain silent on the dehumanization of Africans. One can identify these cardinal coordinates of pedagogy in, for instance, the Black Studies tradition as expressed by Nathan Hare (1969) at San Francisco State University in 1968. While in the UK, these coordinates have historically found expression outside of university in the supplementary school movement as well as in community-based genealogies of Black history, and inside the university (albeit more problematically) with the rise of Black cultural studies.

So in conclusion I want to briefly consider what lessons can be learned from Blyden's pedagogy for those peoples genealogically of the South but resident as postcolonial populations in the North. How might Blyden's aims and methods of liberal education inform present day struggles for epistemic justice for Black peoples in the UK context, one marked by the increasing supremacy of neoliberal logic in higher education?

Using Blyden's method would require (relatively) privileged Black academics in the humanities, arts and social sciences - with support from allies-to develop a curriculum that speaks to the 'laws of growth for the race' as they might be contextualized presently in the UK. That is, such a curriculum would enable and support Black peoples, as postcolonial communities, in the cultivation of 'indigenous' resources through which to address the deep effects of their dehumanization. For this purpose, I would not want to rule out the use of critical thought that references, for example, Foucault, Derrida, Marx or even Spivak; after all, Blyden promoted the teaching of Greek and Arabic to Africans in so far as he judged these classical languages and their cultural reference points to be supportive-or at least not undermining - of African self-edification. But we must ask a question that Blyden did not answer (in his inaugural address at least) regarding the edification of Black lives: when is it that the use of these critical traditions, which are institutionally accepted in the Western academy, become a substitute for the pursuit of epistemic justice for Black peoples? For example, how many of us who research on cognate issues write and (non)reference as if Black Studies is epistemically inferior to postcolonial or post-structural studies (Christian 2006)?

And yet neither can we be satisfied with an all-too-easy importation of Black Studies from the USA. As I have argued, Blyden's natural laws are not, in fact, ontologically racial: they are contextually defined. Our work, then, would be to weave together the various and sometimes competing strands of the living knowledge traditions of African peoples resident in the heart of British empire: yes, by receiving Black studies; but also, by retrieving the Pan-African legacies in the UK (of which Blyden is a part) that precede the second world war, the diverse African-Caribbean politics, arts and philosophies that follow the arrival of the Windrush, the more recent arrival (again) of African-continental lineages of thought and practice, and all the 
wider conversations between diverse postcolonial peoples and even white allies (but not on white terms) which have taken place through these movements. Such a curriculum would be generally edifying: it would tell us something fundamental about struggles over public culture in the UK in and for the world, just as Blyden believed that indigenous traditions of thought would tell us something fundamental about struggles over public culture in Liberia in and for the world.

Meanwhile, Blyden's aim speaks to the current UK context that follows the effective sidelining of the academic movement for epistemic justice by the neoliberal internationalization agenda. Let us remember that Blyden's method of liberal education - the writing of a curriculum that humanizes Africans - must work in conjunction with his aim-to relocate Liberia College to the interior in an equitable fashion. Similarly, we cannot concern ourselves solely with the curriculum. We too must seek to practically co-write this curriculum with the intellectuals and intellectual traditions of our 'interiors', that is, principally, our historically marginalized Black communities. This would impel us to agitate for a redirection of the internationalization agenda - and its concerns for diversity — so that it might work through instead of over the equalities agenda and the resident communities that this latter agenda concretely references.

Once more, such a project would be of general import. For there lies a small opportunity for the redemption of liberal education in the fact that, under neoliberal logic, universities are increasingly expected to instrumentally 'prove' their 'value added' by reference to their 'impact' on either the economy via wealth creation or, perhaps more usefully, on society via social cohesion. However, social cohesion has increasingly become deployed as part of a public discourse of resentment wherein racialized others, rather than neoliberal policies, are blamed for the disintegration of the social compact (see in general Crowley and Hickman 2008). In this respect, public culture, historically racialized, has not been destroyed by neoliberal logics - as some critics think - but has rather become re-racialized through this logic. This is why I am adamant that those who would defend liberal education merely by reference to a dialectic of modernity will struggle to find an adequate language and ethics to defend their liberal education in this new era. They might even consider, paternalistically, that race equality is a distraction from or derivative problem to the destruction of public culture by neoliberal logics. But they are missing the contemporary connection between epistemology and politics, which is race. Not so, in principle, those who have engaged with colonialmodernity and the fundamentally exclusionary constitution of public culture, including its racialized division of communities into those with 'high' and 'low' competencies.

I am arguing that an effective resistance to the neoliberal transformation of universities in defence of liberal education compels a first-order confrontation with epistemic justice. Academics might want to take the lead from a number of mainly student-led movements in the UK, who, inspired by cognate movements in the Global South, are demanding changes to the White curriculum and mono-cultural disposition of the university environment. ${ }^{4}$ They might also choose to be edified by traditions of liberal education that speak more directly and incisively to our current postcolonial conjuncture than those emanating from Oxford and Yale, and Robbins. In this article I have retrieved Blyden's liberal education for Africans. There are others too. ${ }^{5}$ They live, just behind the veil of epistemic ignorance.

\footnotetext{
${ }^{4}$ Follow, for example, https://twitter.com/nusBSC, https://twitter.com/hashtag/whitecurriculum?src=hash, https:// twitter.com/RMF_Oxford, https://twitter.com/ITooAmOxford

${ }^{5}$ See for example Said (2005).
} 
Open Access This article is distributed under the terms of the Creative Commons Attribution 4.0 International License (http://creativecommons.org/licenses/by/4.0/), which permits unrestricted use, distribution, and reproduction in any medium, provided you give appropriate credit to the original author(s) and the source, provide a link to the Creative Commons license, and indicate if changes were made.

\section{References}

Ahmed, S. (2007). The language of diversity. Ethnic and Racial Studies, 30(2), 235-256.

Akpan, M. B. (1973). Blacki: Americo-Liberian rule over the African peoples of Liberia, 1841-1964. Canadian Journal of African Studies, 7(2), 217-236.

Alleyne, B. (2002). Radicals against race: Black activism and cultural politics. Oxford: Berg.

Arnold, M. (2003). Culture and anarchy. Project Gutenberg, Retrieved from http://www.gutenberg.org/cache/ epub/4212/pg4212.html.

Axelrod, P. D. (2002). Values in conflict: the university, the marketplace and the trials of liberal education. Montréal: McGill-Queen's University Press.

Baker, H. A., Jr., Best, S., \& Lindeborg, R. H. (1996). Introduction: representing blackness/representing Britain: cultural studies and the politics of knowledge. In H. A. Baker Jr., M. Diawara, \& R. H. Lindeborg (Eds.), Black british cultural studies: A reader (pp. 1-15). Chicago: University of Chicago Press.

Bell, L., \& Stevenson, H. (2009). Universities in transition: themes in higher education policy. In L. Bell, M. Neary, \& H. Stevenson (Eds.), The future of higher education policy, pedagogy and the student experience (pp. 1-29). London; New York, NY: Continuum.

Bhambra, G. K. (2013). The possibilities of, and for, global sociology: a postcolonial perspective. In J. Go (Ed.), Postcolonial sociology (pp. 295-314). Bingley: Emerald Books.

Bhambra, G. K. (2015, May 24). Committing sociology: defending the public university. Retrieved from http:// www.thesociologicalreview.com/information/blog/committing-sociology-defending-the-public-university. html.

Blyden, E. W. (1882). The aims and methods of a liberal education for Africans. Cambridge: John Wilson and Son.

Blyden, E. W. (1908). The three needs of Liberia-a lecture delivered at lower Buchanan, Grand Bassa County, Liberia, February 26th 1908 (London: C.M. Phillips, 1908). London: C.M. Phillips.

Blyden, E. W. (1971a). Inaugural address at the inauguration of Libera College, at Monrovia, 23rd January 1862. In H. R. Lynch (Ed.), Black spokesman: selected published writings of Edward Wilmot Blyden (pp. 219222). London: Cass.

Blyden, E. W. (1971b). Mr Blyden to Governor Hennessy, 6th December 1872. In H. R. Lynch (Ed.), Black spokesman: selected published writings of Edward Wilmot Blyden (pp. 226-228). London: Cass.

Blyden, E. W. (1971c). To Governor Carter, Department of Native Affairs, 21 st May 1896. In H. R. Lynch (Ed.), Black spokesman: selected published writings of Edward Wilmot Blyden (pp. 256-259). London: Cass.

Blyden, E. W. (1976a). The Liberian scholar. In W. A. Givens (Ed.), Selected works of Dr. Edward Wilmot Blyden (pp. 114-120). Robertsport, Liberia: Tubman Center of African Culture.

Blyden, E. W. (1976b). What can Christians do for Africa. In W. A. Givens (Ed.), Selected works of Dr. Edward Wilmot Blyden (pp. 124-127). Robertsport, Liberia: Tubman Center of African Culture.

Blyden, E. W. (1978a). To J.C. Braman, 15th January 1884. In H. R. Lynch (Ed.), Selected letters of Edward Wilmot Blyden (pp. 314-319). New York: KTO Press.

Blyden, E. W. (1978b). To Sir George Berkeley, 12th February 1874. In H. R. Lynch (Ed.), Selected letters of Edward Wilmot Blyden (pp. 160-165). New York: KTO Press.

Blyden, E. W. (1994). Mohammedanism and the Negro Race. In Christianity, Islam and the negro race (pp. 1947). Baltimore: Black Classic.

Carnochan, W. B. (1993). The battleground of the curriculum: liberal education and American experience. Stanford: Stanford University Press.

Christian, M. (2006). Black studies in the 21st century: longevity has its place. Journal of Black Studies, 36(5), 698-719.

Coard, B., \& Caribbean Education and Community Workers' Association. (1971). How the west Indian child is made educationally subnormal in the British school system: the scandal of the black child in schools in Britain. London: New Beacon for the Caribbean Education and Community Workers' Association.

Collini, S. (2010). Browne's gamble. London Review of Books, 43(21), 23-25.

Committee on Education. (1963). The Robbins report. London: Her Majesty's Stationery Office.

Copleston, E. (1810). A reply to the calumnies of Edinburgh review against Oxford. London: J. Cooke, J. Parker, and J. Mackinlay.

Cronon, W. (1998). 'Only connect...': the goals of a liberal education. The American Scholar, 67(4), 73-80. 
Crowley, H., \& Hickman, M. J. (2008). Migration, postindustrialism and the globalized nation state: social capital and social cohesion re-examined. Ethnic and Racial Studies, 31(7), 1222-1244.

de Sousa Santos, B. (2007). Beyond abyssal thinking: from global lines to ecologies of knowledges. Review (Fernand Braudel Center), 30(1), 45-89.

De Vita, G. \& Case, P. (2003). "Rethinking the internationalisation agenda in UK higher education". Journal of Further and Higher Education, 27(4), 383-398.

Du Bois, W. E. B. (1961). The souls of black folk. New York: Crest Books.

Equality Challenge Unit. (2010). Internationalization and equality and diversity in higher education: merging identities. Retrieved from http://www.ecu.ac.uk/wp-content/uploads/external/internationalisation-equalitydiversity-in-he.pdf.

Gershoni, Y. (1985). Black colonialism: the Americo-Liberian scramble for the hinterland. Boulder: Westview Press.

Gikandi, S. (2007). The ghost of Matthew Arnold: Englishness and the politics of culture. Nineteenth-Century Contexts, 29(2-3), 187-199.

Giroux, H. (1992). Post-colonial ruptures and democratic possibilities: multiculturalism as anti-racist pedagogy. Cultural Critique, 21, 5-39.

Goings, K. W., \& O'Connor, E. (2011). Black Athena before black Athena: the teaching of Greek and Latin at black colleges and universities during the nineteenth century. In D. Orrells, G. K. Bhambra, \& T. Roynon (Eds.), African Athena: New agendas (pp. 90-105). Oxford: Oxford University Press.

Grosfoguel, R. (2007). The epistemic decolonial turn: beyond political-economy paradigms. Cultural Studies, 21(2-3), 211-223.

Gutzmore, C. (1982). The Notting Hill carnival. Marxism Today, (August), 31-33.

Hall, S. (1990). The emergence of cultural studies and the crisis of the humanities. October, 53, 11-23.

Hare, N. (1969). A conceptual proposal for a department of black studies. In Shut it down! A college in crisis (pp. 159-167). Washington D.C: U.S. Government Printing Office.

Harris, S. (2005). Rethinking academic identities in neo-liberal times. Teaching in Higher Education, 10(4), 421433.

Henry, W. (2006). What the deejay said: a critique from the street! London: Nu-Beyond Ltd.

Herbst, J. (2004). The Yale report of 1828. International Journal of the Classical Tradition, 11(2), 213-231.

Higton, M. (2012). A theology of higher education. Oxford: Oxford University Press.

Holmwood, J. (2011). A manifesto for the public university. London: Bloomsbury Academic.

Icaza, R., \& Vázquez, R. (2013). Social struggles as epistemic struggles. Development and Change, 44(3), 683704.

Jarratt, S. C. (2009). Classics and counterpublics in nineteenth-century historically black colleges. College English, 72(2), 134-159.

Keet, A. (2014). Epistemic 'othering' and the decolonization of knowledge. Africa Insight, 44(1), $23-37$.

Kim, T. (2009). Transnational academic mobility, internationalization and interculturality in higher education. Intercultural Education, 20(5), 395-405.

Leerssen, J. (2006). Englishness, ethnicity and Matthew Arnold. European Journal of English Studies, 10(1), 6379.

Lentin, A. (2005). Replacing 'race', historicizing 'culture' in multiculturalism. Patterns of Prejudice, 39(4), 379396.

Livingston, T. W. (1972). Liberia college: West African outpost of the American college Movement, presented at the 15th annual meeting of the African Studies Assoc, 1972. In Annual Meeting of the African Studies Association.

Lynch, H. R. (1978). Introduction. In Selected letters of Edward Wilmot Blyden (pp. 1-55). New York: KTO Press.

Mignolo, W. (2011). The darker side of western modernity: global futures, decolonial options. Durham: Duke University Press.

Mirza, H. S., \& Reay, D. (2000). Spaces and places of black educational desire: rethinking black supplementary schools as a new social movement. Sociology, 34(03), 521-544.

Mohanty, C. T. (1989). On race and voice: challenges for liberal education in the 1990s. Cultural Critique, 14, 179-208.

Moses, W. J. (1998). Liberian dreams: back-to-Africa narratives from the 1850s. University Park, PA: Pennsylvania State University Press.

Newman, J. H. (2008). The idea of a university defined and illustrated in nine discourses delivered to the catholics of Dublin. Project Gutenberg, Retrieved from http://www.gutenberg.org/files/24526/24526-h/ 24526-h.html.

Nussbaum, M. (2004). Liberal education and global community. Liberal Education, 90(1), 42-47. 
Nussbaum, M. (2010). Not for profit: why democracy needs the humanities. Princeton: Princeton University Press.

Oakeshott, M. (2004). The idea of a university. Academic Questions, 17(1), 23-30.

Owosu, K. (2000). Introduction: charting the genealogy of black British cultural studies. In K. Owosu (Ed.), Black British culture and society: a text reader (pp. 1-18). New York: Routledge.

Restrepo, P. (2014). Legitimation of knowledge, epistemic justice and the intercultural university: towards an epistemology of 'living well'. Postcolonial Studies, 17(2), 140-154.

Said, E. W. (2005). On the university / جدمة . Alif: Journal of Comparative Poetics, 25, $26-36$.

Seth, S. (2007). Subject lessons: the western education of colonial India. Durham: Duke University Press.

Shilliam, R. (2015). The black pacific: anticolonial struggles and oceanic connections. London: Bloomsbury Academic.

Shore, C. (2010). Beyond the multiversity: neoliberalism and the rise of the schizophrenic university. Social Anthropology, 18(1), 15-29.

Slee, P. R. H. (1986). Learning and a liberal education: the study of modern history in the universities of Oxford, Cambridge, and Manchester, 1800-1914. Manchester: Manchester University Press.

Solomos, J. (2001). Race, multiculturalism and difference. In N. Stevenson (Ed.), Culture and citizenship (pp. 198-211). London: Sage.

Stromquist, N. P. (2007). Internationalization as a response to globalization: radical shifts in university environments. Higher Education, 53(1), 81-105.

The Higher Education Academy. (2014). Internationalising higher education framework. Retrieved from https:// www.heacademy.ac.uk/sites/default/files/resources/internationalisingheframeworkfinal.pdf.

The National Committee of Inquiry into Higher Education. (1997). The Dearing report. London: The National Committee of Inquiry into Higher Education.

Tibebu, T. (2012). Edward Wilmot Blyden and the racial nationalist imagination. Rochester: Rochester University Press.

Tyler-McGraw, M. (2007). An African republic: black \& white Virginians in the making of Liberia. Chapel Hill: University of North Carolina Press. Retrieved from http://public.eblib.com/choice/publicfullrecord.aspx?p= 880448.

Young, R. (1995). Colonial desire: hybridity in theory, culture, and race. London: Routledge. 